\title{
PATENT REGISTRATION SYSTEM IN INDONESIA
}

\author{
DEVI RISTA \\ NPM 155100019 \\ Fakultas Komputer, KDV 4487571591 \\ devirista.student@umitra.ac.id
}

\begin{abstract}
Patent rights are a form of protection of intellectual property rights granted by the state to inventors for the results of their inventions in the field of technology, which for a certain period of time carry out their own inventions or give their consent to other parties to implement them. and the First to Invent System, a system adopted by the Indonesian government in giving patent rights to proposers, the Indonesian government refers to the First to File System. In Article 34 UUP stated "If for one of the same inventions it turns out that more than one applicant has been filed by a different applicant, only the application submitted first or first is acceptable.
\end{abstract}

Keywords: Patent and Patent Registration 


\section{A. INTRODUCTION}

The 4th material discusses the category of the patent registration system.

a. How many types of patent registration systems?

There are 2 types of patent registration systems, namely?

1. First to File System

2. First to Invent system

b. First to File System

The First to File system is a system that provides patents for those who register first for new inventions in accordance with the requirements.

c. First to Invent system

The First to Invent system is a system that provides patents for those who find the first innovation according to predetermined requirements.

d. What system is adopted by the Indonesian government?

In giving patent rights to proposers, the Indonesian government refers to the First to File System.

e. What is the claim?

Claims are the most important part of an invention (invention) that is requested for protection, and in the claim disclosed all the technical advantages of the invention.

f. What is the difference between a patent with a simple patent (Utility Models)?

\begin{tabular}{|l|l|l|l|}
\hline No. & \multicolumn{1}{|c|}{ Simple } & \multicolumn{1}{|c|}{ Patent } & \multicolumn{1}{|c|}{$\begin{array}{c}\text { Patent } \\
\text { Description }\end{array}$} \\
\hline 1. & The Checked & $\begin{array}{l}\text { Novelty (Novelly). } \\
\text { Inventive step, can be } \\
\text { applied in the novelly } \\
\text { industry }\end{array}$ & $\begin{array}{l}\text { Novelty } \\
\text { (novelly) }\end{array}$ \\
\hline 2. & The validity & $\begin{array}{l}\text { is 20 years, starting from } \\
\text { the receipt of the patent } \\
\text { application. }\end{array}$ & $\begin{array}{l}10 \text { years, } \\
\text { starting from the } \\
\text { date of the grant } \\
\text { of the patent }\end{array}$ \\
\hline 3. & Number of Claims & $\begin{array}{l}1 \text { (one) or more than one } \\
1 \text { (one) }\end{array}$ & (one) \\
\hline
\end{tabular}




\section{QUIZ Selected Section Class}

According to Law No. 14 of 2001, Patents mean exclusive rights granted by the state to inventors for the results of their inventions in the field of technology, which for a certain period of time carry out their own inventions or give their approval to other parties to implement them. How to Register Intellectual Property Rights, Patents, Copyright, Trademarks. In the case of patents, there is a provision that the patent holder must carry out his patent in the territory of Indonesia. That means, he must produce patents in Indonesia, ranging from investment, employment, to technology transfer issues. How to Register Intellectual Property Rights, Patents, Copyright, Trademarks.

For domestic patent procedures, it is stated that:

1. Patent applicants must fulfill all requirements.

2. The Director General of Intellectual Property Rights will announce it 18 (eighteen) months after the date of receipt of the patent application.

3. The announcement lasts for 6 (six) months to find out whether there are objections or not from the community.

4. If this announcement stage is passed and the patent application is accepted, the patent applicant has the right to obtain his patent rights for a period of 20 (twenty) years from the date of the filling date. How to Register Intellectual Property Rights, Patents, Copyright, Trademarks.

The registration procedures imposed by the Director General of IPR are as follows:

1. A Patent Application is submitted by filling in the form provided, in Indonesian, which is then typed in 4 (four).

2. In the process of registering this patent, the applicant must also attach the following:

3. Special Power of Attorney, if the patent registration application is submitted through a Patent consultant registered as the attorney;

- Letter of transfer of rights, if the application is submitted by another party who is not the inventor;

-Descriptions, claims, abstracts and images (if any) each of 3 (three) copies;

- Original Priority Evidence, and 4 (four) front page translations in Indonesian (if submitted with Priority Rights);

- Translation of the description of the invention in English, if the invention is originally in a foreign language other than English, made in duplicate 2 (two);

- Proof of payment of Patent application fees of Rp. 575,000 (five hundred seventy five thousand rupiahs); and How to Register Intellectual Property Rights, Patents, Copyright, Trademarks. 
1. Proof of payment of a Simple Patent application fee of Rp. 125,000 (one hundred twenty five thousand rupiahs) and for a Simple Patent substantive examination of Rp. 350,000 (three hundred fifty thousand rupiahs); - Additional costs for each claim, if more than 10 (ten) claims: Rp. 40,000 (forty thousand rupiahs) per claim.

1. Writing the description, claim, abstract and image as referred to above are determined as follows:

- Each sheet of paper is only one of its faces that can be used for writing and drawing;

- Descriptions, claims and abstracts are typed in HVS paper or similar which are separated by size A-4 $(29.7 \times 21 \mathrm{~cm})$ with a minimum weight of 80 grams with a limit: from the upper edge of $2 \mathrm{~cm}$, from the bottom edge of $2 \mathrm{~cm}$, from the edge left $2.5 \mathrm{~cm}$, and from the right edge $2 \mathrm{~cm}$; How to Register Intellectual Property Rights, Patents, Copyright, Trademarks.

- The A-4 paper must be white, the average is not shiny and its use is done by placing its short sides at the top and bottom (unless used for pictures);

- Each description sheet, claims and drawings are numbered in Arabic numerals in the upper center;

- In every five lines of typing and claim lines, must be given a line number and each new page is the beginning (beginning) of the number and placed to the left of the description or claim: How to Register Intellectual Property Rights, Patents, Copyright, Trademarks.

- Typing must be done using black ink (toner), with sizes between lines of 1.5 spaces, with upright letters the minimum letter height is $0.21 \mathrm{~cm}$;

- Signs with lines, chemical formulas, and certain signs can be written by hand or painted;

- Images must use black Chinese ink on A-4 size white drawing paper with a minimum weight of 100 grams which is not glossy with the following limits: from the top $2.5 \mathrm{~cm}$, from the bottom edge $1 \mathrm{~cm}$, from the left edge $2.5 \mathrm{~cm}$, and from the right edge $1 \mathrm{~cm}$;

- All Patent documents submitted must be in sheets of whole paper, may not be torn, folded, damaged or affixed images;

- Every term used in descriptions, claims, abstracts and images must be 
consistent with each other. How to Register Intellectual Property Rights, Patents, Copyright, Trademarks.

2. An application for a substantive examination is submitted by filling in the form provided for it in the Indonesian language by attaching proof of payment of the application fee of Rp. 2,000,000 (two million rupiah).

\section{B. CONCLUSION}

The conclusion of this material is

There are 2 types of patent registration systems, first to file system and first to inventory system, a system adopted by the Indonesian government in giving patent rights to proposers, the Indonesian government refers to the First to File System. In Article 34 UUP stated "If for one of the same inventions it turns out that more than one applicant has been filed by a different applicant, only the application submitted first or first is acceptable.

For domestic patent procedures, it is stated that:

1. Patent applicants must fulfill all requirements.

2. The Director General of Intellectual Property Rights will announce it 18 (eighteen) months after the date of receipt of the patent application.

3 . The announcement lasts for 6 (six) months to find out whether there are objections or not from the community.

4. If this announcement stage is passed and the patent application is accepted, the patent applicant has the right to obtain his patent rights for a period of 20 (twenty) years from the date of the filling date. How to Register Intellectual Property Rights, Patents, Copyright, Trademarks.

\section{ACKNOWLEDGEMENT}

University Of Indonesia

University Of Mitra Indonesia

Telkom University

University Of Mellbourne

Saitama University 


\section{REFERENCE(Based ISO 690 )}

[1] A. S. Putra And O. M. Febriani, "Knowledge Management Online Application In Pdam Lampung Province," In Prosiding International Conference On Information Technology And Business (Icitb), 2018, Pp. 181-187.

[2] A. S. Putra, O. M. Febriani, And B. Bachry, "Implementasi Genetic Fuzzy System Untuk Mengidentifikasi Hasil Curian Kendaraan Bermotor Di Polda Lampung," J. Sist. Inf. Dan Manaj. Basis Data, Vol. 1, No. 1, Pp. 21-30, 2018.

[3] O. M. Febriani And A. S. Putra, "Sistem Informasi Monitoring Inventori Barang Pada Balai Riset Standardisasi Industri Bandar Lampung," J. Inform., Vol. 13, No. 1, Pp. 90-98, 2014.

[4] Putra, Arie Setya. "2018 Artikel Struktur Data, Audit Dan Jaringan Komputer." (2018).

[5] Putra, A. S. (2018, July 17). Paperplain Fundamental Create Application With Borland Delphi 7.0 University Of Mitra Indonesia. Retrieved From Osf.Io/Pbrn9.

\section{E. REFERENCE(Based APA )}

Putra, A. S., Aryanti, D. R., \& Hartati, I. (2018, November). Metode SAW (Simple Additive Weighting) sebagai Sistem Pendukung Keputusan Guru Berprestasi (Studi Kasus: SMK Global Surya). In Prosiding Seminar Nasional Darmajaya (Vol. 1, No. 1, pp. 85-97).

Sari, D. P., Febriani, O. M., \& Putra, A. S. (2018, November). Perancangan Sistem Informasi SDM Berprestasi pada SD Global Surya. In Prosiding Seminar Nasional Darmajaya (Vol. 1, No. 1, pp. 289-294).

Putra, A. S. (2018). Paperplain: Execution Fundamental Create Application With Borland Delphi 7.0 University Of Mitra Indonesia.

Putra, A. S., Sukri, H., \& Zuhri, K. Sistem Monitoring Realtime Jaringan Irigasi Desa (JIDES) Dengan Konsep Jaringan Sensor Nirkabel. IJEIS (Indonesian Journal of Electronics and Instrumentation Systems), 8(2), 221-232.

Darmawan, A., Yuliawati, D., Marcella, O., \& Firmandala, R. (2016). Sistem Absensi dan Pelaporan Berbasis Fingerprint dan SMS Gateway. EXPLORE, 7(1).

Febriani, O. M., Wahyuni, T., \& Yusuf, S. (2017). DESIGN OF WEBSITE-BASED INFORMATION SYSTEM FOR EDOCUMENT ADMINISTRASI IN THE 
COMMUNITY SERVICE UNIT (A Case Study at Rajabasa District). INTERNATIONAL JOURNAL OF COMPUTERS \& TECHNOLOGY, 16(7), 70107020.

Febriani, O. M., \& Wahyuni, T. (2017, October). PERANCANGAN SISTEM EDOCUMENT ADMINISTRASI LOGBOOK PENELITIAN PADA UNIT LAYANAN DI BANDAR LAMPUNG. In Prosiding Seminar Nasional Darmajaya (Vol. 1, No. 1, pp. 187-194).

Febriani, O. M., \& Permadi, A. B. (2017). Implementasi Sistem Aplikasi Data Bimbingan dan Pelanggaran Siswa pada Sekolah Menengah Atas di Lampung Tengah dengan Metode Analisis dan Desain Sistem Terdistribusi (SSAD). EXPERT, $7(1)$.

Febriani, O. M., \& Ambarwati, L. (2015). PERANCANGAN APLIKASI PENGOLAHAN DATA PENJUALAN UKM KELANTING KHAS TELO DESA SIDOHARJO KECAMATAN JATI AGUNG KABUPATEN LAMPUNG SELATAN. Jurnal Teknologi Informasi dan Bisnis Pengabdian Masyarakat Darmajaya, 1(1), 77-95.

Febriani, O. M. (2015). Rancang Bangun Aplikasi E-commercemenggunakan Freewebstore pada UKM Kelanting di Desa Sidoharjo Lampung Selatan. Prosiding Sembistek 2014, 1(02), 446-458. 